\title{
FORMATION OF INTERETHNIC TOLERANCE OF FUTURE PRESCHOOL EDUCATORS IN THE PROFESSIONAL TRAINING PROCESS
}

\author{
ФОРМУВАННЯ МІЖЕТНІЧНОЇ ТОЛЕРАНТНОСТІ \\ МАЙБУТНІХ ВИХОВАТЕЛІВ ДОШКІЛЬНОЇ ОСВІТИ \\ У ПРОЦЕСІ ПРОФЕСІЙНОЇ ПІДГОТОВКИ \\ ILONA DYCNKIVSKA, \\ doctor of Pedagogical Sciences, \\ professor \\ https://orcid.org/0000-0002-9353-5666 \\ ІЛОНА ДИЧКІВСЬКА, \\ доктор педагогічних наук, \\ профресор \\ ilonardgu@gmail.com \\ Rivne State \\ Humanitarian University, \\ $\triangle 12$ S. Bandery St., \\ Rivne city, 33028 \\ Рівненський державний \\ гуманітарний університет, \\ $\triangle$ вул. С. Бандери, 12 \\ м. Рівне, 33028 \\ Original manuscript received: July 10, 2019
}

Revised manuscript accepted: September 02, 2019

\begin{abstract}
The article reveals the concept of "tolerance" as a complex integrative quality of the individual, psychological and social aspects of comprehension and understanding of the phenomenon of tolerance. The concept of "interethnic tolerance" is characterized as theability of a person to establish positive relationships with others and the world at large, to form their own positive image. The vision of the concept of "interethnic tolerance" is justified as the perception of others as the yare, along with the willingness to interact with them.

It is proved that the successful formation of interethnic tolerance among students - future educators of preschool children depends on the creation of certain pedagogical conditions, namely: providing cooperation with various socio-cultural institutes of the region; specification (concretization) of informative component of professional training of future preschool educator taking into consideration specificity of activity in multicultural environment through establishmentof transdisciplinary, competent (competencial) and situational approaches.(development of special courses of multicultural direction); creation of a single tolerant space for higher education institutions; formation of a tolerance setting (establishing, directing), which implies the readiness and ability of the heads of higher education institutions, teachers and students to engage in equal dialogue through synergistic interaction; variative use of teaching and training( educating) methods thatactivate the development of student tolerance; developing the skills of communicative tolerance of all participants of the educational process; implementation of programs to increase the psychological and pedagogical competence of doctors; providing personal-oriented interaction of teachers and students in the training and educational process and in extracurricular activity, through which the skills of communicative tolerance are realized, prerequisites for the successful development of tolerant qualities come up.
\end{abstract}


Key words: tolerance, intolerance, interethnic tolerance, multicultural education, sociocultural tolerance, ethnos, future preschool educators.

Постановка проблеми. Розбудова України як демократичної, правової та мультикультурної держави вимагає консолідації українського суспільства на принципах мирного та плідного співіснування різних соціальних груп. Концепція розвитку освіти України на 2015-2025 роки (2014) свідчить, що одним із провідних завдань освітніх установ $€$ виховання людини в дусі толерантності. Реформування вищої ланки державної системи освіти передбачає пошук інноваційних підходів щодо організації освітнього процесу, розроблення нових стандартів підготовки вихователів дошкільної освіти - майбутніх фахівців, здатних виховувати особистість на засадах толерантності.

У “Декларації принципів толерантності" (1995), затвердженій резолюцією Генеральної конференції ЮНЕСКО, наголошується, що виховання в дусі толерантності потрібно розглядати як безальтернативний імператив і в зв'язку з цим необхідно досягати систематичного і раціонального виховання толерантності, що висвітлює культурні, соціальні, економічні, політичні, релігійні джерела нетерпимості, які лежать в основі насильства і відчуження [3]. Освітні програми повинні сприяти поліпшенню солідарності і терпимості у відносинах як між окремими людьми, так і між етнічними, соціальними, культурними, релігійними і мовними групами, а також націями.

На міжнародному освітньому форумі, що відбувся в березні 2019 року з нагоди вручення світової щорічної премії Global Teacher Prize працівникам освітньої сфери, що здійснили видатний внесок у професію, толерантність була зазначена як найважливіша складова сучасної освіти, адже освіта - це запорука толерантності. I тільки освічені люди здатні прийняти глобальні виклики та принести мир на нашу планету.

Проблема професійного становлення педагога та його діяльності в умовах поліетнічного регіону потребує особливої уваги, адже сучасні політичні реалії вимагають толерантної взаємодії з багатонаціональними дитячими і батьківським колективами, що $€$ можливим лише за умови сформованості полікультурної компетентності фахівця, яка включає: культурологічні, етноісторичні знання, вміння виокремлювати і привносити до змісту загальної освіти ідеї, що відображають культурне різноманіття світу; уміння організувати педагогічний процес як діалог носіїв різних культур у часі та просторі. Це передбачає: усвідомлення своїх спонукань до полікультурної діяльності у багатонаціональному середовищі - потреб та інтересів, прагнень, ціннісних орієнтацій, мотивів; оцінку своїх особистісних властивостей і якостей як майбутнього фахівця, готового до здійснення своєї професійної діяльності у полікультурному освітньому просторі; формування міжетнічної толерантності та регулювання на цій основі свого професійного становлення відповідно до умов роботи в такому суспільстві.

Аналіз досліджень і публікацій. Проблема толерантності стала об'єктом наукових досліджень відносно недавно. У сучасному 
глобальному світі люди відчувають потребу в розумінні людей іншої культури, релігії, цінностей, моральних норм тощо.

3 іншого боку, усе більшої гостроти набувають конфлікти, прояви расової та національної дискримінації, екстремізму. Все більше країн стикаються з проблемами нетерпимого ставлення одних людей до інших в умовах сучасної полікультурності суспільства. Особливо важливою $є$ проблема подолання різних форм прояву нетерпимості серед молоді та досягнення згоди і безконфліктного спілкування у суспільстві.

Необхідністю вирішення цілої низки завдань гармонізації соціальних відносин у суспільстві й було зумовлено появу фундаментальних робіт, присвячених толерантності. Особливої уваги проблема толерантності набула у $90-\mathrm{x}$ роках XX ст.

Толерантність означає "повагу, прийняття і правильне розуміння багатого різноманіття культур нашого світу, наших форм самовираження i способів вияву людської індивідуальності. Їй сприяють знання, відвертість, спілкування і свобода думки, совісті і переконань. Толерантність - це гармонія в різноманітті. Це не тільки моральний обов'язок, але й політична і правова потреба. Толерантність - це чеснота, яка робить можливим досягнення миру і сприяє заміні культури війни культурою миру" [3].

Прояв толерантності, який співзвучний повазі прав людини, не означає терпимого ставлення до соціальної несправедливості, відмови від своїх або поступки чужим переконанням. Це означає, що кожен вільний дотримуватися своїх переконань і визнає таке ж право за іншими. Це означає визнання того, що люди за своєю природою розрізняються за виглядом, положенням, мовою, поведінкою й цінностями і володіють правом жити у світі та зберігати свою індивідуальність. Це також означає, що погляди однієї людини не можуть бути нав'язані іншим [3, с. 87].

Таким чином, з одного боку, толерантність $є$ соціально важливою якістю особистості, а з іншого - перед системою освіти кожної країни постає проблема формування толерантності у своїх громадян, особливо молоді. Це освітянське завдання підкреслюється також і в Декларації принципів толерантності: "виховання у дусі толерантності слід розглядати як невідкладний імператив; у зв'язку з цим необхідно заохочувати методи систематичного й раціонального навчання толерантності, що розкривають культурні, соціальні, економічні, політичні та релігійні джерела нетерпимості, які лежать в основі насильства і відчуження. Політика і програми у ссрері освіти повинні сприяти поліпшенню взаєморозуміння, зміцненню солідарності й терпимості в стосунках як між окремими людьми, так і між етнічними, соціальними, культурними, релігійними і мовними групами, а також націями" [3, с. 87]. У Декларації також підкреслюється важливість наукових досліджень у сфері виховання «у дусі толерантності».

Як свідчить аналіз наукових праць, проблема толерантності досліджувалася в різних напрямах: проведено теоретичний аналіз поняття "толерантність" 3 позиції філософії (Ю. Бромлей, Р. Валітова, 
В. Лекторський), психології (О. Асмолов, Г. Балл, О. Леонтьєв та ін.), педагогіки (І. Бех, І. Зязюн, В. Петрицький, П. Степанов), визначено шляхи формування окремих видів толерантності (В. Бойко, О. Грива, І. Гриншпун, А. Жадан, Н. Лебедєва, О. Лункова), висвітлено роль толерантності у професійній діяльності фрахівців різного профрілю, зокрема вчителів і вихователів, та технології ії формування (І. Дичківська, Л. Капустіна, $€$. Карякіна, Г. Косарєва, Н. Чернуха та ін.), розкрито аксіологічні основи вдосконалення професійної діяльності педагогів (Н. Асташова,

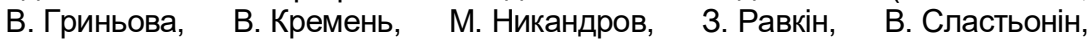
О. Сухомлинська). Проблеми міжетнічної толерантності осмислюються в працях таких науковців, як Т. Атрощенко, М. Баліашвілі, О. Грива, О. Гуренко, І. Данилюк, Л. Дробіжева, В. Євтух, Л. Залановська, І. Залєсова, М. Михайлова, Л. Орбан-Лембрик, М. Пірен, А. Погодіна, П. Дж. Роуз, Л. Тогебі, М. Уолцер, М. Хараджи, Д. Хейд, Р. Шермерхорн та ін.

Незважаючи на вагомий внесок науковців у дослідження проблеми виховання толерантності педагогів, зокрема виховання міжетнічної толерантності майбутніх вихователів дітей дошкільного віку, рівень її сформованості на практиці в цілому залишається незадовільним, що вимагає продовження наукового пошуку в даному напрямі.

Метою статті $\epsilon$ визначення педагогічних умов формування толерантності майбутніх вихователів дітей дошкільного у процесі профресійної підготовки.

Виклад матеріалу. Для визначення педагогічних умов формування міжетнічної толерантності у майбутніх вихователів дошкільної освіти слід проаналізувати сутність феномену "міжетнічна толерантність".

Характеристика явища "міжетнічна толерантність" базується на концептуальних засадах, узагальнених і викладених у Декларації принципів толерантності, прийнятої ЮНЕСКО у 1995 році [3], хоч окремі аспекти проблеми міжетнічної толерантності дослідники почали розробляти задовго до цього.

Міжетнічна толерантність, на наш погляд, $€$ важливою якістю особистості, яка передбачає взаєморозуміння і взаємоповагу до іншої нації, етносу, культури, конфресії.

Для української мови поняття "толерантність" відносно нове і поки що не має однозначного тлумачення. В енциклопедичних словниках цей термін найчастіше ототожнюється 3 "терпимістю". Так, слово "толерантність" - похідне від французького "tolerant", що означає терпимий. Подібні приклади синонімічності зазначених понять містяться і в інших мовах. Наприклад, у німецькій: "duldsamkeit" - терпимість і "toleranz" - толерантність, терпимість. Великий тлумачний словник сучасної української мови трактує толерантність як поблажливе, терпиме ставлення до чиїхось думок, поглядів, вірувань тощо [2, с. 289]. Подібним чином пояснює це поняття і "Сучасний словник іншомовних слів": толерантність - це терпимість, поблажливість до кого-небудь, чогонебудь [8, с. 300]. 
Однак, хочемо зауважити, що толерантність не зводиться до простої терпимості. Терпимість підкреслює спосіб ставлення до неприємних або неприйнятних об'єктів - поблажливе їх допущення або вимушене терпіння без застосування насильства. За такою зовнішньою формою поведінки часто приховується внутрішня ворожість і незнання іншого. Ми вважаємо, що на відміну від терпимості толерантність передбачає право особи на збереження ії автономії. Як якість особистості толерантність передбачає налаштованість на паритетний діалог, на пізнання нового, “чужого", а також не виключає можливості зміни системи поглядів і уявлень індивіда" [8, с. 590].

У наукових дослідженнях феномен толерантності найчастіше розглядається в контексті міжетнічних відносин, тому значна кількість наукових праць присвячена саме міжнаціональній та міжетнічній толерантності, обґрунтуванню їх змісту і структури, а також проблемам їх формування. Низка вітчизняних і зарубіжних досліджень із соціології, педагогіки та психології вивчають також понятт соціокультурної та міжкультурної (етнокультурної) толерантності. Соціокультурною толерантністю у вузькому смислі вважається прояв терпимого ставлення до представників певної соціальної категорії та носіїв певної субкультури. У широкому розумінні поняття соціокультурної толерантності певним чином порівнюють 3 терміном міжкультурної толерантності, оскільки він розглядається вченими як "моральна якість особистості, що характеризує її терпиме ставлення до інших людей, незалежно від їх етнічної, національної та культурної приналежності, терпиме ставлення до інших поглядів, звичаїв, звичок". У цьому випадку терміну "соціокультурний", практично ідентичними за значеннями $є$ поняття "етнічний" та "етнокультурний", які $є$ базовими у визначенні поняття міжетнічної толерантності.

У етносоціології дається визначення міжетнічної толерантності як здатності людини виявляти терпимість до малознайомого способу життя представників інших спільнот, їх поведінки, національних традицій, звичаїв, почуттів, ідей, вірувань. Підкреслюється, що ця здатність може підвищуватися або знижуватися в залежності від наявності у людини досвіду спілкування з представниками інших етнічних груп. У науковій педагогічній літературі міжетнічна толерантність визначається як активна моральна позиція і психологічна готовність до терпимості в ім'я позитивної взаємодії з людьми іншої культури, нації, релігії, соціального середовища [9]. Г. Палаткіна розглядає толерантність у сфрері міжнаціонального спілкування як визнання цінності "Іншого", цінності різноманітності, "інакшості", право на плюралізм поглядів [6, с. 70]. Трактування поняття "міжетнічна толерантність" В. Петренком практично збігається за змістом з поняттям толерантності взагалі: “...міжетнічна толерантність - визнання самоцінності будь-якої іншої людини, визнання права людини бути несхожою, іншою, прийняття її такою, якою вона $€ "$ " [7, с. 43].

Ми поділяємо точку зору дослідниці 3. Мубінової, яка розглядає досліджуваний феномен як системну сукупність психологічних установок, почуттів, визначеного набору знань і суспільно правових норм 
(виражених через закон або традиції), а також світоглядно-поведінкових орієнтацій, які передбачають толерантне ставлення представників однієї нації до інших, до національних явищ (мови, культури, звичаїв, норм поведінки і т.д.) [5, с. 28]. Уважаємо, що міжнаціональна толерантність представляє собою процес, що постійно розвивається і включає в себе: 1) власне емоційно-психічні норми, почуття по відношенню до інших національностей; 2) широкий набір знань, інформаційних уявлень про інші культури, мови; 3) власне поведінкові установки, світоглядні погляди стосовно інших мови, культури, звичаїв, норм поведінки і т.д. [4, с. 34].

Велике значення у формуванні етнотолерантності особистості мають автоідентифікація та гетероідентифікація, культурна самоідентифікація та ідентифікація «інших» культур. Національна самосвідомість являє собою не просто віднесення людьми себе до тієї чи іншої національності, а більш складне самовизначення людини, яке включає і національний спосіб мислення і життя, і уявлення про територію, традиції, культуру, мову, самобутність народу та його історичне існування в світі. Тому, на наш погляд, необхідно більш глибоко вивчити проблему взаємозв'язку загальнолюдського, соціально-групового і національного в культурі народів того чи іншого регіону та виявити її виховний потенціал.

Отже, міжетнічна толерантність - складний соціально-психологічний феномен життєдіяльності сучасного суспільства, який необхідно вивчати всебічно. На нашу думку, міжетнічна толерантність є потужною якістю особистості, яка $є$ найбільш ефективною у формуванні взаєморозуміння і взаємоповаги до іншої нації, етносу, культури, раси, конфесії тощо.

Успішне формування міжетнічної толерантності у студентівмайбутніх вихователів дошкільної освіти залежить, на наш погляд, від створення певних педагогічних умов, а саме: забезпечення співпраці 3 різними соціокультурними інститутами регіону; конкретизації змістовного компонента професійної підготовки майбутнього вихователя з урахуванням специфіки діяльності в полікультурному середовищі через запровадження трансдисциплінарного, компетентнісного та ситуативного підходів (розробка спецкурсів полікультурного спрямування); створення єдиного толерантного простору закладів вищої освіти; формування установки на толерантність, що передбачає готовність і здатність керівників закладів вищої освіти, педагогів та студентства до рівноправного діалогу через синергетичну взаємодію; варіативне використання методів навчання і виховання, що активізують розвиток толерантності студентів.

Дослідниця Т. Атрощенко для формування міжетнічної толерантності майбутніх педагогів визначає такі умови: формування навичок комунікативної толерантності всіх учасників освітнього процесу; реалізація програм підвищення психолого-педагогічної компетентності педагогів; забезпечення особистісно-орієнтованої взаємодії педагогів і студентів у навчальному та виховному процесі та в позанавчальній діяльності, завдяки якій реалізуються навички комунікативної 
толерантності, виникають передумови для успішного розвитку толерантних якостей [1, с. 25].

Дослідник Н. Якса зазначає, що в основу кардинальних змін у системі професійної підготовки майбутніх педагогів покладено певні методологічні засади, які визначають роль педагога як суб'єкта полікультурного середовища. Ця роль випливає із провідних філософських ідей стосовно сучасних світових концепцій, що поширюються в освітньому просторі: концепція глобалізації, що передбачає відповідність педагогічної освіти особливостям глобального розвитку, об'єднання кращих інтелектуальних ресурсів, міжнародне співробітництво в освітній сфрері, побудоване на засадах діалогу і взаємопроникнення культур; концепція регіоналізації (локалізації) про відповідність педагогічної освіти регіональним полікультурним особливостям; положення про розвиток культур корінних народів та етнічних груп; розвиток локального партнерства міжкультурної взаємодії в освіті; відповідність навчальних програм педагогічної підготовки майбутніх учителів потребам регіону; концепція індивідуалізації, спрямована на посилення у майбутніх учителів мотивації, ініціативи, творчості в навчанні; їх залучення до світової та національної спадщини; розвиток ціннісних орієнтацій, знань, технологій, норм поведінки; розвиток особистісного потенціалу майбутнього педагога в соціальному, культурному, освітньому аспектах [10, с. 64].

Сутність і зміст міжетнічної толерантності майбутнього вихователя закладу дошкільної освіти характеризує її як результат успішної реалізації потенційних якостей педагога в складних умовах поліетнічної та полікультурної людської спільноти, існування якої залежить від здійснення оптимальних форм міжетнічних стосунків і взаємодій.

Відповідно, в якості основної умови фрормування міжетнічної толерантності виступає включення толерантності в особисту систему цінностей студентів - майбутніх вихователів дітей дошкільного віку, для перетворення толерантності в принцип, який повинен бути покладеним в основу їхньої подальшої професійної діяльності. Важливим засобом вирішення цього завдання $є$ освіта, оскільки саме її метою $є$ всебічний і гармонійний розвиток особистості майбутніх педагогів, тому що тільки розвинена особистість, людина високої загальної культури здатна толерантно поводитися і мислити.

Висновки. Для реалізації педагогічних умов фрормування міжетнічної толерантності майбутніх вихователів дошкільної освіти у процесі професійної підготовки необхідно домагатись єдності національного та міжнаціонального; глибоко вивчати настрої студентів, враховувати їх у повсякденній практиці навчально-виховної роботи, при цьому використовувати можливості студентського колективу; виховувати культуру міжнаціонального спілкування на основі культурологічного підходу, який передбачає єдність двох компонентів - зовнішнього (суб'єкти спілкування, вербальний або інший процес спілкування та опосередковуючі його ланки) і внутрішніх (когнітивні і ціннісні 
детермінанти); постійно спиратися на принцип діалектичної єдності двох основ вищої освіти: національної та світової (дає змогу людині глибоко відчувати приналежність до рідного народу, водночас усвідомлювати себе суб'єктом світової цивілізації; удосконалювати психологопедагогічну підготовку студентів до роботи з дітьми дошкільного віку, до розвитку культури міжнаціонального спілкування в дитячих колективах. Перспективним для подальших досліджень $€$ розробка структурнодинамічної моделі формування етнотолерантної свідомості у студентівмайбутніх вихователів закладів дошкільної освіти.

\section{Література}

1.Атрощенко Т.О. Особливості організації практики майбутніх учителів початкових класів в умовах поліетнічного регіону: методичні рекомендації для студентів спеціальності 013 “Початкова освіта" / Т.О. Атрощенко. - Мукачево: МДУ, 2018. - 65 с.

2.Великий тлумачний словник сучасної української мови / уклад. і голов. ред. В. Т. Бусел. - К.: Ірпінь: ВТФ “Перун”, 2009. - 1736 с.

3.Декларация принципов толерантности // Век толерантности: научнопублицистический вестник. - 2001. - № 1-2. - С. 131-137.

4. Дичківська І.М. Г.М. Формування толерантності у майбутніх вихователів дошкільних навчальних закладів до дітей з особливими потребами: монографія / І.М. Дичківська, Г.М. Косарєва. - Рівне: Поліграф, 2018. - 204 с.

5. Мубинова 3. Этнонациональное воспитание в современном мире: теоретические и концептуальные подходы / 3. Мубинова. - Уфа, 2007. -176 с.

6. Палаткина Г. В. Формирование этнотолерантности у младших школьников / Г. В. Палаткина // Начальная школа. - 2003. - № 11. - С. 65-72.

7. Петренко В. Психосемантический анализ этнических стереотипов: лики толерантности и нетерпимости / В. Петренко, О. Митина, К. Бердников, А. Кравцова, В. Осипова. - М. : Смысл, 2000. - 73 с.

8. Словник іншомовних слів /за ред. О. С. Мельничука. - 2-е видання, випр. і доп. Київ: Головна редакція “Українська радянська енциклопедія” (УРЕ), 1985. - 966 с.

9. Степанов Є.П. Формування культури міжетнічних відносин у студентів вищих навчальних закладів / Є.П. Степанов // автореф. дис. на здобуття наук. ступ. канд.. пед. наук: 13.00.07. - Луганськ., 2004. - 20 с.

10. Якса Н.В. Педагог як суб'єкт полікультурного середовища / Н. В. Якса // Вісник Житомирського державного університету імені Івана Франка. - 2010. № 50. - С. 64-67.

\section{References}

1. Atroshhenko, T.O. (2018). Osoblyvosti orhanizatsiyi praktyky maybutnikh uchyteliv pochatkovykh klasiv $v$ umovakh polietnichnoho rehionu: metodychni rekomendatsiyi dlya studentiv spetsialnosti 013 "Pochatkova osvita» [Features of the organization of the practice of future teachers of elementary school in conditions of polyethnic region: methodical recommendations for students of specialty 013 «Primary education»]. Mukachevo: MDU. [in Ukrainian].

2. Velykyy tlumachnyy slovnyk suchasnoyi ukrayins'koyi movy (2009) [Great Dictionary of Modern Ukrainian]. K.: Perun, 1736 p. [in Ukrainian].

3. Deklaracija principov tolerantnosti (2001) [Declaration of Principles of Tolerance]. Age of Tolerance: The Scientific and Publicistic Herald, 1-2, p.131-137. [in Russian].

4. Dychkivska, I. M. (2018) Formuvannya tolerantnosti u maybutnikh vikhovateliv doshkilnykh navchalnykh zakladiv do ditey z osoblyvymy potrebamy [Formation of tolerance of the future preschool educators to children with special needs]: Monografiya / 
I.M. Dychkivska. G. M. Kosareva. Rivne: Poligraf. 204 s. [in Ukrainian].

5. Mubinova, Z. (2007) Etnonatsionalnoye vospitaniye $v$ sovremennom mire: teoreticheskiye $i$ kontseptualnyye podkhody [Ethnonational education in the modern world: theoretical and conceptual approaches]. Ufa. 176 s.[in Russian].

6. Palatkina, G. V. (2003) Formirovanie jetnotolerantnosti u mladshih shkol'nikov [Formation of ethnotolerance in younger schoolchildren]. Primary School,11, p. 65-72. [in Russian].

7. Petrenko, V. (2000) Psikhosemanticheskiy analiz etnicheskikh stereotipov: liki tolerantnosti i neterpimosti [Psychosemantic analysis of ethnic stereotypes: faces of tolerance and intolerance] / V. Petrenko, O. Mitina, K. Berdnikov, A. Kravtsova, V. Osipova. M. : Smysl. 73 s. [in Russian].

8. Slovnyk inshomovnykh sliv (1985). [Dictionary of foreign words]. Kiev. (URE), 966 p. [in Ukrainian].

9. Stepanov E.P. (2004) Formuvannya kultury mizhetnichnykh vidnosyn u studentiv vyshchikh navchalnykh zakladiv [Building a culture of inter-ethnic relations of university students] / E.P. Stepanov // Abstract dis. kand. ped. sc.: 13.00.07. Lugansk. 20 p. [in Ukrainian].

10. Yaksa N.V. (2010), Pedahoh yak subiekt polikulturnoho seredovyshcha [The teacher as a subject of a multicultural environment], Journal Zhytomyr State University named after Ivan Franko, 50, pp. 64-67. [in Ukrainian].

\section{АНОТАЦІЯ}

У статті розкриваються поняття "толерантність" як складна інтегративна якість особистості, психологічні та соціальні аспекти осмислення і розуміння цього френомену. Схарактеризовано поняття "міжетнічна толерантність" як здатність людини налагоджувати позитивні взаємини з іншими та світом у цілому, формувати власний позитивний образ. Обгрунтовано власне бачення поняття "міжетнічна толерантність" як сприйняття інших такими, якими вони є, поряд із готовністю взаємодіяти з ними.

Доведено, що успішне формування міжетнічної толерантності у студентів - майбутніх вихователів дітей дошкільного віку залежить від створення певних педагогічних умов, а саме: забезпечення співпраці з різними соціокультурними інститутами регіону; конкретизації змістовного компонента профресійної підготовки майбутнього вихователя дошкільної освіти 3 урахуванням специфіки діяльності в полікультурному середовищі через запровадження трансдисциплінарного, компетентнісного та ситуативного підходів (розробка спецкурсів полікультурного спрямування); створення єдиного толерантного простору закладів вищої освіти; фрормування установки на толерантність, що передбачає готовність $і$ здатність керівників закладів вищої освіти, педагогів та студентства до рівноправного діалогу через синергетичну взаємодію; варіативне використання методів навчання $i$ виховання, що активізують розвиток толерантності студентів; формування навичок комунікативної толерантності всіх учасників освітнього процесу; реалізація програм підвищення психолого-педагогічної компетентності педагогів; забезпечення особистісно-орієнтованої взаємодії педагогів $і$ студентів у навчальному та виховному процесі та у позанавчальній діяльності, завдяки якій реалізуються навички комунікативної толерантності, виникають передумови для успішного розвитку толерантних якостей.

Ключові слова: толерантність, інтолерантність, міжетнічна толерантність, полікультурна освіта, соціокультурна толерантність, етнос, майбутні вихователі дошкільної освіти. 